\title{
Three New Steroidal Glycoalkaloids from Solanum pseudoquina A. St.-Hil. (Solanaceae)
}

\author{
Vitor Soares, ${ }^{a}$ Thaís A. Bezerra, ${ }^{a}$ Rita C. A. Lafetá, ${ }^{b}$ Ricardo M. Borges ${ }^{a}$ and \\ Antonio Jorge R. da Silva*,a
}

\author{
${ }^{a}$ Instituto de Pesquisas de Produtos Naturais Walter Baptist Mors, \\ Universidade Federal do Rio de Janeiro, 21941-902 Rio de Janeiro-RJ, Brazil
}

${ }^{b}$ FAETEC, 25804-020 Rio de Janeiro-RJ, Brazil

\begin{abstract}
Three new steroidal glycoalkaloids (SGA) were isolated from green berries of Solanum pseudoquina A. St.-Hil. The extract obtained after treatment with $5 \%$ acetic acid aqueous solution was subjected to several chromatographic procedures, leading to an enriched alkaloidal fraction. The enriched alkaloidal fraction was subjected to a semi preparative high performance liquid chromatography (HPLC) leading to the isolation of three new SGA from $S$. pseudoquina: 3-O-( $\beta$ - $D$-glucopyranosyl) (20S,25S)-22,26-epimino-16 $\alpha$-acetyl-cholesta-22(N)-ene, 3-O-( $\beta$ - $D$-glucopyranosyl) $(20 R, 25 \xi)-23,26$-epimino-16 $\alpha$-acetyl-cholesta-5,23( $N)$-dien-22-one and 3-O-( $\beta$ - $D$-glucopyranosyl) $(20 S, 25 \xi)$-23,26-epimino-16 $\alpha$-acetyl-cholesta-5,23( $N$ )-dien-22-one. The structures of the new compounds were elucidated with the help of 1D and 2D nuclear magnetic resonance (NMR) and infrared spectroscopy together with high resolution electrospray ionization and atmospheric pressure chemical ionization mass spectrometry.
\end{abstract}

Keywords: solanaceae, Solanum pseudoquina A. St.-Hil., steroidal glycoalkaloid

\section{Introduction}

Solanum pseudoquina A. St.-Hil. belongs to the Solanaceae family, and is popularly known as "quina de São Paulo". This plant is endemic in Brazil, and its bark is traditionally used as tonic and febrifuge in the Brazilian southern region. ${ }^{1}$ Many species of bitter tasting plants, as S. pseudoquina, have been used in Brazil as substitutes of Cinchona spp., the source of quinine, used in the treatment of intermittent fevers. ${ }^{2}$

Plants of the genus Solanum, with approximately 1400 species, are widespread in the tropical and temperate zones. The genus Solanum is the predominating taxon for steroidal alkaloids (SA) within the Solanaceae. ${ }^{3}$ Usubillaga et al. ${ }^{4}$ reported the isolation, from $S$. pseudoquina, of the alkaloid solaquidine (3,3-dimethoxy-22 $\beta, 25 \xi$-22,26epimino-5 $\xi$-cholestane). In 1987, the same author used partial synthesis to establish the absolute configuration of the natural compound as $5 \alpha, 22 S$ and $25 R .{ }^{5}$ Later, the isolation from $S$. pseudoquina of the steroidal alkaloid $(25 S)$-isosolafloridine as well as the demonstration of its

*e-mail: ajorge@nppn.ufrj.br convulsive effect were reported, ${ }^{6}$ but no further studies with the alkaloidal fractions of $S$. pseudoquina were reported since then. Steroidal alkaloids and their glycoside derivatives (steroidal glycoalkaloids, SGA) have been isolated from a comprehensive number of Solanum plants. For example, the toxicity of SGA from blighted, green, or sprouted potato (S. tuberosum) tubers (solanine and chaconine), is well documented ${ }^{7}$ and has been motivating the research efforts on plant breeding in order to reduce SGA levels in potatoes. Additional interest regarding steroidal alkaloids is due to its antifungal and anticancer activities: solasodine rhamnosyl glycosides as solamargine and solasonine, specifically induce apoptosis in cancer cells and these cells do not develop resistance to this class of compounds. ${ }^{8}$

In the present report we communicate the isolation of three new steroidal glycoalkaloids from $S$. pseudoquina: 3-O-( $\beta$ - $D$-glucopyranosyl) $(20 S, 25 S)$-22,26-epimino- $16 \alpha$ acetyl-cholesta-22(N)-ene, 1; 3-O-( $\beta$ - $D$-glucopyranosyl) $(20 S, 25 \xi)-23,26$-epimino- $16 \alpha$-acetyl-cholesta-5,23(N)dien-22-one, 2 and its isomer 3- $O$-( $\beta$ - $D$-glucopyranosyl) $(20 R, 25 \xi)-23,26$-epimino- $16 \alpha$-acetyl-cholesta-5,23( $N)$ dien-22-one, 3 . The first compound is an isosolafloridine 
steroidal type alkaloid lacking a double bond between C-5 and C- $6 .{ }^{9}$ The other two compounds are isomeric solaspiralidine steroidal type alkaloids similar to the steroidal alkaloid isolated from roots of Solanum spirale by Ripperger. ${ }^{10}$ The three compounds were isolated from the aqueous acidic extract of berries of $S$. pseudoquina and were structurally characterized by $1 \mathrm{D}$ and $2 \mathrm{D}$ nuclear magnetic resonance (NMR), high-resolution electrospray ionization mass spectrometry (HRESIMS), atmospheric pressure chemical ionization mass spectrometry (APCIMS) along with infrared spectroscopy (IR) and optical rotation measurements.

\section{Experimental}

\section{General procedures}

$\mathrm{KBr}$ pellet IR spectra were recorded on an IRPrestige-21 Shimadzu FTIR spectrophotometer (Kyoto, Japan). Optical rotations were measured in a P-2000 Jasco polarimeter (Tokyo, Japan) using methanol as solvent. NMR spectra were recorded on a Varian VNMRSYS $500 \mathrm{MHz}$ spectrometer (Varian Inc., Palo Alto, CA, USA) working at $499.78\left({ }^{1} \mathrm{H}\right)$ and at $125.68 \mathrm{MHz}\left({ }^{13} \mathrm{C}\right)$. The pulse sequences used are all standard in the VNMRJ software, and the experiments were conducted at $25{ }^{\circ} \mathrm{C}$. Samples were dissolved in $0.3 \mathrm{~mL}$ of pyridine- $d_{5}(\mathbf{1})$ or $\mathrm{CD}_{3} \mathrm{OD}$ (2 and $\left.\mathbf{3}\right)$ and transferred to $3 \mathrm{~mm}$ NMR tubes. Mass analyses were carried out on a Bruker MicroTOF II (Bruker Daltonics, Bremen, Germany) mass spectrometer equipped with both electrospray ionization (ESI) and atmospheric pressure chemical ionization (APCI) interfaces and controlled by COMPASS software. All samples were dissolved in methanol. For all HRESIMS analyses the parameters were: flow of $180 \mathrm{~mL} \mathrm{~h}^{-1}$; positive ion polarity; capillary set $4500 \mathrm{~V}$; dry gas flow of $5.0 \mathrm{~L} \mathrm{~min}^{-1}$ and nebulizer at 0.5 Bar. For all APCIMS experiments the parameters were: flow of $0.150 \mathrm{~mL} \mathrm{~min}^{-1}$; positive ion polarity; capillary set $4000 \mathrm{~V}$; dry gas flow of $3.0 \mathrm{~L} \mathrm{~min}^{-1}$ and nebulizer at 2.5 Bar. Semi preparative high performance liquid chromatography (HPLC) was carried out using two parallel LC-10AS pumps, coupled to a SPD-10A UV-Vis detector, a CTO-10A column oven and a C-R6A integrator (Shimadzu, Kyoto, Japan).

\section{Plant material}

Fruits from $S$. pseudoquina were collected in Rio de Janeiro, Brazil, by Rita de Cássia Almeida Lafetá, FAETEC (Fundação de Apoio à Escola Técnica do Rio de Janeiro). A voucher specimen RFA40631 was deposited at the Herbário
RFA, Departamento de Biologia, CCS, Universidade Federal do Rio de Janeiro, Rio de Janeiro-RJ, Brazil.

\section{Extraction and isolation}

The fruits from $S$. pseudoquina were weighed (300 g) and pulverized in a laboratory blender with aqueous $5 \%$ acetic acid solution $(1 \mathrm{~L})$ at room temperature for $5 \mathrm{~min}$. A 30 min ultrasonic assisted extraction was then performed. The solution was filtered over Celite ${ }^{\circledR}$ and the residue was re-extracted with a new $1 \mathrm{~L}$ volume of acid solution. The aqueous acidic extracts were applied to an open column $(50 \times 6 \mathrm{~cm})$ filled with $250 \mathrm{~g}$ of XAD-2 resin previously washed with pure methanol and then conditioned with 5\% aqueous acetic acid solution. After applying the extract to the XAD-2 column, a column wash with $500 \mathrm{~mL}$ methanol:water (1:1) was done. An enriched SGA fraction was obtained with another column wash with pure methanol (1 L). The methanol fraction from XAD-2 was dried under vacuum at $45^{\circ} \mathrm{C}$ producing $11.4 \mathrm{~g}$ of residue. Around $4.85 \mathrm{~g}$ of the residue were dissolved in $250 \mathrm{~mL}$ of aqueous $1 \%$ acetic acid and concentrated $\mathrm{NH}_{4} \mathrm{OH}(28 \%)$ was added to force precipitation of the alkaloids. A crude mixture of SGA was obtained after centrifugation (1.9 g). Half of the crude mixture was subjected to column chromatography over silica (25 g) with mobile phase $\mathrm{CH}_{2} \mathrm{Cl}_{2}: \mathrm{MeOH}: 2 \%$ aqueous $\mathrm{NH}_{4} \mathrm{OH}(650: 350: 50$, v/v/v) and $6 \mathrm{~mL}$ fractions were collected. After repeating the column chromatography procedure, fractions 3 to 7 from both separations were pooled to yield, after evaporation, the alkaloidal fraction GA33 (404.6 mg). GA33 was further subjected to silica gel column chromatography, with mobile phase $\mathrm{CH}_{2} \mathrm{Cl}_{2}: \mathrm{MeOH}: 2 \%$ aqueous $\mathrm{NH}_{4} \mathrm{OH}(785: 200: 15 \mathrm{v} / \mathrm{v} / \mathrm{v})$ and $6 \mathrm{~mL}$ collected fractions, to give GA33A (198.0 mg) from fractions 6 to 12. All silica gel chromatography were carried out at room temperature with flow of $12 \mathrm{~mL} \mathrm{~min}^{-1}$.

The GA33A fraction was subjected to semi preparative HPLC in isocratic mode: $70 \%$ (methanol) and $30 \%$ (ammonium formate buffer $50 \mathrm{mmol} \mathrm{L}^{-1}, \mathrm{pH} 4$ ) yielding: $3(5.2 \mathrm{mg})$ and $2(5.7 \mathrm{mg})$ along with unresolved early eluting peaks. The unresolved fraction was subjected to further HPLC separation (52\% methanol and $48 \%$ ammonium formate buffer $50 \mathrm{mmol} \mathrm{L}^{-1}$ ), yielding 1 (4.2 mg). All HPLC runs were carried out at a flow rate of $5 \mathrm{~mL} \mathrm{~min}{ }^{-1}$ and column temperature of $30{ }^{\circ} \mathrm{C}$.

3-O-( $\beta$-D-Glucopyranosyl) (20S,25S)-22,26-epimino$16 \alpha$-acetyl-cholesta-22 $(N)$-ene (1)

White solid; mp 222-227 ${ }^{\circ} \mathrm{C}$ (dec.); $[\alpha]_{\mathrm{D}}{ }^{25}-46^{\circ}$ ( $c 0.420$, $\mathrm{MeOH})$; IR (KBr) $v_{\max } / \mathrm{cm}^{-1} 3423(\mathrm{O}-\mathrm{H}), 2929,2854(\mathrm{C}-\mathrm{H})$, 1730, 1651 (C=N), 1591, 1456, 1379, 1247, 1076, 1033; 
HRESIMS (positive ion mode) protonated molecular ion at $m / z, 620.4154[\mathrm{M}+\mathrm{H}]^{+}$(calcd. for $\mathrm{C}_{35} \mathrm{H}_{58} \mathrm{NO}_{8}, 620.4157$ ), fragments at $m / z 560.3943\left[(\mathrm{M}+\mathrm{H})-\mathrm{CH}_{3} \mathrm{CO}_{2} \mathrm{H}\right]^{+}$and $m / z 430.9139\left[\left(\mathrm{M}+\mathrm{H}+\mathrm{CH}_{3} \mathrm{OH}\right)-\mathrm{CH}_{3} \mathrm{CO}_{2} \mathrm{H}-162.0528\right.$ (hexose residue) $]^{+}$.

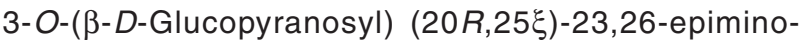
$16 \alpha$-acetyl-cholesta-5,23( $N)$-dien-22-one (2)

White solid; $\mathrm{mp} 137-148^{\circ} \mathrm{C}$ (dec.); $[\alpha]_{\mathrm{D}}^{25}-60^{\circ}$ (c 0.150, $\mathrm{MeOH})$; IR (KBr) $v_{\max } / \mathrm{cm}^{-1} 3425(\mathrm{O}-\mathrm{H}), 2960,2933$, $2854(\mathrm{C}-\mathrm{H}), 1732(\mathrm{C}=\mathrm{O}), 1685(\mathrm{C}=\mathrm{N}), 1438,1377,1242$, 1076, 1033; HRESIMS (positive ion mode) protonated molecular ion at $\mathrm{m} / z 632.3798[\mathrm{M}+\mathrm{H}]^{+}$(calcd. for $\mathrm{C}_{35} \mathrm{H}_{54} \mathrm{NO}_{9}, 632.3793$ ) and $m / z 654.3627[\mathrm{M}+\mathrm{Na}]^{+}$(calcd. for $\left.\mathrm{C}_{35} \mathrm{H}_{53} \mathrm{NNaO}_{9}, 654.3613\right)$; APCIMS ion mass fragments: $m / z 572\left[(\mathrm{M}+\mathrm{H})-\mathrm{CH}_{3} \mathrm{CO}_{2} \mathrm{H}\right]^{+}, m / z 470[(\mathrm{M}+\mathrm{H})-162$ (hexose residue $)]^{+}, m / z 410\left[(\mathrm{M}+\mathrm{H})-\mathrm{CH}_{3} \mathrm{CO}_{2} \mathrm{H}-162\right.$ (hexose residue) $]^{+}$.

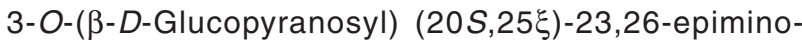
$16 \alpha$-acetyl-cholesta-5,23(N)-dien-22-one (3)

White solid; mp $130-141^{\circ} \mathrm{C}$ (dec.); $[\alpha]_{\mathrm{D}}{ }^{25}-109^{\circ}$ (c 0.270, MeOH); IR (KBr) $\mathrm{v}_{\max } / \mathrm{cm}^{-1} 3427(\mathrm{O}-\mathrm{H}), 2933$, $2854(\mathrm{C}-\mathrm{H}), 1734(\mathrm{C}=\mathrm{O}), 1691(\mathrm{C}=\mathrm{N}), 1458,1379,1247$, 1078, 1031; HRESIMS (positive ion mode) protonated molecular ion at $\mathrm{m} / \mathrm{z} 632.3790[\mathrm{M}+\mathrm{H}]^{+}$(calcd. for $\mathrm{C}_{35} \mathrm{H}_{54} \mathrm{NO}_{9}, 632.3793$ ) and $m / z 654.3619[\mathrm{M}+\mathrm{Na}]^{+}$(calcd. for $\left.\mathrm{C}_{35} \mathrm{H}_{53} \mathrm{NNaO}_{9} 654.3613\right)$; APCIMS ion mass fragments: $m / z 572\left[(\mathrm{M}+\mathrm{H})-\mathrm{CH}_{3} \mathrm{CO}_{2} \mathrm{H}\right]^{+}, m / z 470[(\mathrm{M}+\mathrm{H})-162$ (hexose residue $)]^{+}, m / z 410\left[(\mathrm{M}+\mathrm{H})-\mathrm{CH}_{3} \mathrm{CO}_{2} \mathrm{H}-162\right.$ (hexose residue) $]^{+}$.

\section{Results and Discussion}

The aqueous acidic extract of $S$. pseudoquina berries was subjected to chromatographic purification over a XAD-2 resin and repeated silica gel column chromatography, followed by semi preparative HPLC purification, to afford three new compounds (1, 2, and 3) (Figure 1).

Compound 1, a white powder with molecular formula $\mathrm{C}_{35} \mathrm{H}_{57} \mathrm{NO}_{8}$, determined by positive HRESIMS, displayed a protonated molecular ion at $m / z 620.4154[\mathrm{M}+\mathrm{H}]^{+}$ $\left(\mathrm{C}_{35} \mathrm{H}_{58} \mathrm{NO}_{8}\right.$, calcd. 620.4157). Fragment ions were observed at $\mathrm{m} / \mathrm{z} 560.3943\left[(\mathrm{M}+\mathrm{H})-\mathrm{CH}_{3} \mathrm{CO}_{2} \mathrm{H}\right]^{+}$and $\mathrm{m} / z 430.9139$ $\left[\left(\mathrm{M}+\mathrm{H}+\mathrm{CH}_{3} \mathrm{OH}\right)-\mathrm{CH}_{3} \mathrm{CO}_{2} \mathrm{H}-162.0528\right.$ (hexose residue) $]^{+}$. The ${ }^{1} \mathrm{H}$ NMR spectrum of compound $\mathbf{1}$ (Table 1) displayed two superimposed three proton singlet resonances at $\delta 0.65(\mathrm{H}-18$ and $\mathrm{H}-19)$ assigned to two steroidal angular methyl groups and two three proton doublet signals at 1.13 $\left(\mathrm{d},{ }^{3} J_{\mathrm{HH}} 6.9 \mathrm{~Hz}, \mathrm{H}-21\right)$ and $0.83\left(\mathrm{~d},{ }^{3} J_{\mathrm{HH}} 6.6 \mathrm{~Hz}, \mathrm{H}-27\right)$,

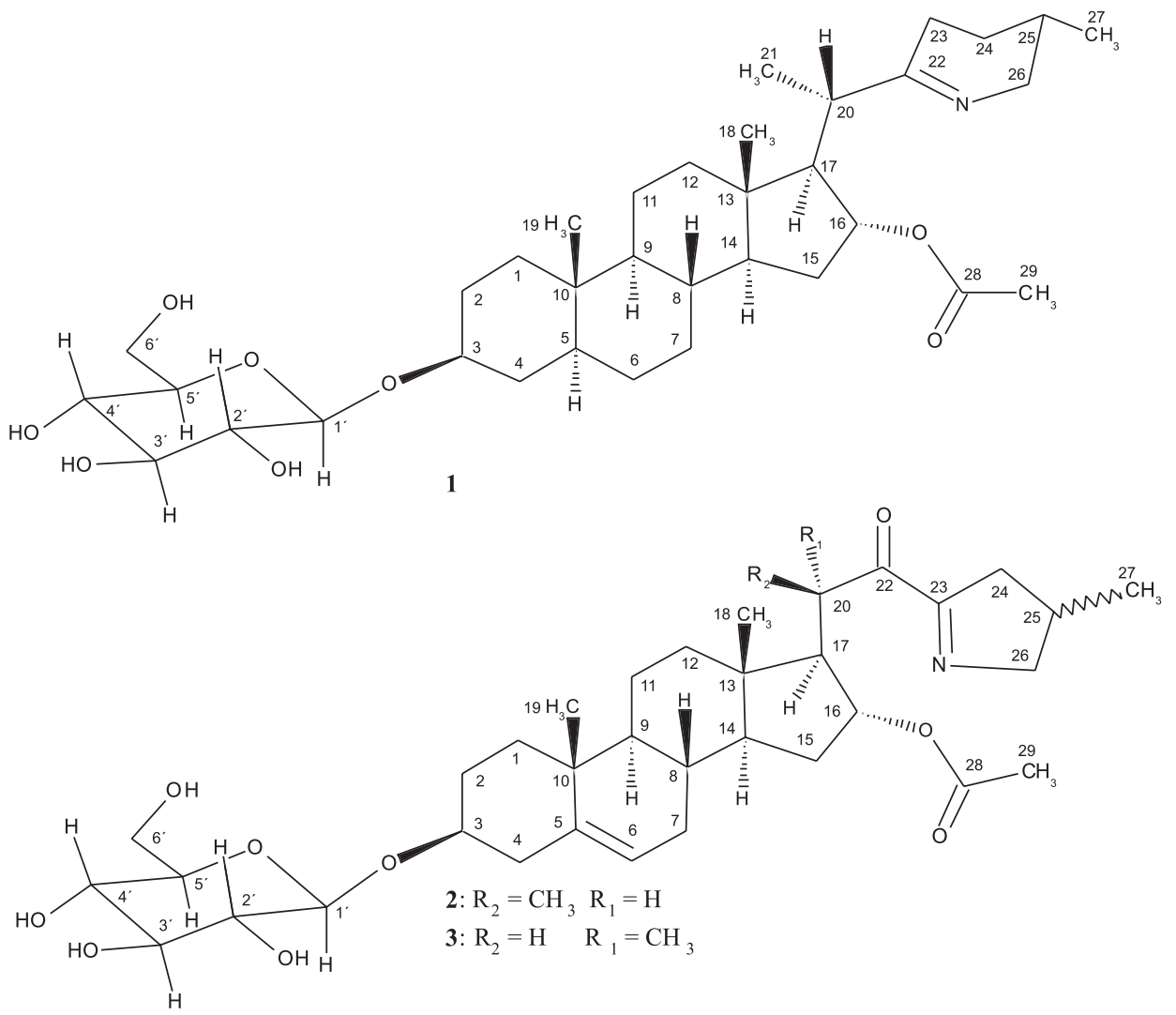

Figure 1. Chemical structures of the alkaloids isolated from S. pseudoquina berries. 
characteristic of a steroidal alkaloid skeleton. ${ }^{11}$ The ${ }^{13} \mathrm{C}$ NMR spectrum of $\mathbf{1}$ exhibited 35 signals, consistent with a steroidal alkaloid plus one acetyl and one hexose residues. The edited heteronuclear single quantum coherence (HSQC) spectrum allowed the identification of five methyl groups (the one at $\delta 21.47$ assigned to acetyl group, C-29), twelve methylene and fourteen methine groups. The remaining four nonhydrogenated carbons were identified as: $\delta 170.40$ (ester carbonyl, C-28), 43.79 (C-13), 173.13 (C-22) and 35.71 (C-10). All these carbons were assigned with the help of a heteronuclear multiple bond correlation (HMBC) spectrum. The methyl groups correlations in the HMBC spectrum provided starting points to help assigning the remaining hydrogens and carbons in the steroidal backbone. The free rotation of these groups keeps the values for ${ }^{2} J_{\mathrm{C}, \mathrm{H}}$ and ${ }^{3} J_{\mathrm{C}, \mathrm{H}}$ around $4.5-6 \mathrm{~Hz}$, allowing the detection of all expected methyl correlations. ${ }^{12}$ From the HMBC correlation map, the mutual ${ }^{2} J_{\mathrm{C}, \mathrm{H}} / 3 J_{\mathrm{C}, \mathrm{H}}$ carbon/hydrogen correlations led to the identification of a sequence including 13 out of the 27 carbons in the aglycone as seen on Figure 2.

Table 1. NMR spectral data (499.78 MHz, ${ }^{1} \mathrm{H}$ and $\left.125.68 \mathrm{MHz},{ }^{13} \mathrm{C}\right)$ for $\mathbf{1}, \mathbf{2}$ and $\mathbf{3}$

\begin{tabular}{|c|c|c|c|c|c|c|}
\hline & \multicolumn{3}{|c|}{${ }^{13} \mathrm{C} \delta / \mathrm{ppm}$} & \multicolumn{3}{|c|}{${ }^{1} \mathrm{H} \delta / \mathrm{ppm}$} \\
\hline & $\mathbf{1}^{\mathrm{a}}$ & $2^{\mathrm{b}}$ & $3^{\mathrm{b}}$ & $\mathbf{1}^{\mathrm{a}}$ & $2^{\mathrm{b}}$ & $3^{\mathrm{b}}$ \\
\hline 1 & 37.12 & 38.50 & 38.52 & $1.54 ; 0.79$ & $1.84 \mathrm{dt}(3.6 ; 13.3 \mathrm{~Hz}) ; 1.07 \mathrm{~m}$ & $1.87 ; 1.09$ \\
\hline 2 & 30.00 & 30.76 & 30.75 & $2.06 ; 1.63$ & $1.91 ; 1.59$ & $1.93 ; 1.59$ \\
\hline 3 & 77.20 & 79.86 & 79.90 & $3.97\left(\mathrm{~m}^{\mathrm{c}}\right)$ & $3.58 \mathrm{tt}(11.3 ; 4.5 \mathrm{~Hz})$ & $3.58 \mathrm{tt}(11.3 ; 4.5 \mathrm{~Hz})$ \\
\hline 4 & 34.81 & 39.75 & 39.89 & $1.83 ; 1.40$ & $\begin{array}{l}2.42 \mathrm{dd}(5.0 ; 12.7 \mathrm{~Hz}) ; \\
2.24 \mathrm{t}(12.5 \mathrm{~Hz})\end{array}$ & $\begin{array}{l}2.43 \mathrm{t}(11.6 \mathrm{~Hz}) \\
2.26 \mathrm{dd}(11.6 \mathrm{~Hz})\end{array}$ \\
\hline 5 & 44.56 & 142.09 & 142.28 & 0.88 & - & - \\
\hline 6 & 28.82 & 122.47 & 122.56 & 1.11 & $5.36 \mathrm{~d}(4.34 \mathrm{~Hz})$ & $5.36 \mathrm{~d}(5.2 \mathrm{~Hz})$ \\
\hline 7 & 32.16 & 32.85 & 32.87 & $1.44 ; 0.78$ & $1.94 ; 1.55$ & $1.94 ; 1.55$ \\
\hline 8 & 34.86 & 32.65 & 32.71 & 1.19 & 1.47 & 1.50 \\
\hline 9 & 54.25 & 51.56 & 51.55 & 0.55 & 0.97 & 1.03 \\
\hline 10 & 35.71 & 37.93 & 37.96 & - & - & - \\
\hline 11 & 21.11 & 21.78 & 21.90 & $1.40 ; 1.15$ & $1.50 ; 1.34$ & $1.59 ; 1.52$ \\
\hline 12 & 40.11 & 40.30 & 40.89 & $1.87 ; 1.21$ & $1.23 ; 1.08$ & $1.42 ; 2.05$ \\
\hline 13 & 43.79 & 44.16 & 45.11 & - & - & - \\
\hline 14 & 53.78 & 54.66 & 54.98 & 1.30 & 1.33 & 1.33 \\
\hline 15 & 34.98 & 35.45 & 35.18 & $1.71 ; 1.60$ & $1.77 \alpha ; 1.52 \beta$ & $1.74 \alpha ; 1.43 \beta$ \\
\hline 16 & 79.48 & 79.43 & 79.85 & 5.27 & $5.05 \mathrm{t}(7.7 \mathrm{~Hz})$ & $5.02 \mathrm{t}(7.6 \mathrm{~Hz})$ \\
\hline 17 & 59.15 & 59.49 & 60.84 & 1.87 & $2.09 \mathrm{dd}(7.5 ; 10.7 \mathrm{~Hz})$ & $1.77 \mathrm{dd}(6.9 ; 10.7 \mathrm{~Hz})$ \\
\hline 18 & 13.39 & 14.91 & 13.74 & $0.65 \mathrm{~s}$ & $0.73 \mathrm{~s}$ & $0.85 \mathrm{~s}$ \\
\hline 19 & 12.25 & 19.90 & 19.91 & $0.65 \mathrm{~s}$ & $0.99 \mathrm{~s}$ & $1.04 \mathrm{~s}$ \\
\hline 20 & 46.16 & 40.57 & 41.25 & $2.63 \mathrm{dq}(7.0 ; 11.5 \mathrm{~Hz})$ & $3.83 \mathrm{~m}$ & $3.93 \mathrm{dq}(6.9 ; 10.7 \mathrm{~Hz})$ \\
\hline 21 & 18.23 & 16.98 & 16.75 & $1.13 \mathrm{~d}(6.9 \mathrm{~Hz})$ & $1.00 \mathrm{~d}(7.0 \mathrm{~Hz})$ & $1.11 \mathrm{~d}(6.8 \mathrm{~Hz})$ \\
\hline 22 & 173.13 & 204.43 & 204.07 & - & - & - \\
\hline 23 & 26.21 & 175.13 & 175.66 & $2.20 ; 2.20$ & - & - \\
\hline 24 & 27.94 & 42.72 & 42.39 & $1.68 ; 1.18$ & $\begin{array}{c}2.90 \mathrm{ddt}(2.9 ; 8.7 ; 18 \mathrm{~Hz}) ; \\
2.35 \mathrm{~m}\end{array}$ & $\begin{array}{l}2.75 \mathrm{ddt}(2.3 ; 8.8 ; 17.7 \mathrm{~Hz}) \\
2.34 \mathrm{ddt}(2.3 ; 6.0 ; 17.7 \mathrm{~Hz})\end{array}$ \\
\hline 25 & 27.69 & 32.40 & 32.55 & 1.53 & $2.50 \mathrm{~m}$ & $2.43 \mathrm{ddd}(2.2 ; 4.9 ; 13.3 \mathrm{~Hz})$ \\
\hline 26 & 56.88 & 70.73 & 70.59 & $\begin{array}{c}3.80 \mathrm{dd}(4.6 ; 17.0 \mathrm{~Hz}) \\
3.11 \mathrm{dd}(9.5 ; 17.0 \mathrm{~Hz})\end{array}$ & $\begin{array}{c}4.21 \mathrm{ddt}(2.6 ; 7.7 ; 17.5 \mathrm{~Hz}) \\
3.74 \mathrm{~m}\end{array}$ & $\begin{array}{l}4.19 \mathrm{ddt}(2.3 ; 7.9 ; 17.3 \mathrm{~Hz}) \\
3.66 \mathrm{ddt}(2.3 ; 5.5 ; 17.3 \mathrm{~Hz})\end{array}$ \\
\hline 27 & 19.28 & 20.54 & 20.16 & $0.83 \mathrm{~d}(6.6 \mathrm{~Hz})$ & $1.02 \mathrm{~d}(6.91 \mathrm{~Hz})$ & $1.03 \mathrm{~d}(6.6 \mathrm{~Hz})$ \\
\hline $16-\mathrm{CO}$ & 170.40 & 172.70 & 172.50 & - & - & - \\
\hline $\mathrm{CH}_{3}$ & 21.47 & 21.41 & 21.32 & $2.10 \mathrm{~s}$ & $2.02 \mathrm{~s}$ & $1.89 \mathrm{~s}$ \\
\hline 1 ' & 102.22 & 102.25 & 102.55 & $5.05 \mathrm{~d}(7.7 \mathrm{~Hz})$ & $4.37 \mathrm{~d}(7.8 \mathrm{~Hz})$ & $4.38 \mathrm{~d}(7.8 \mathrm{~Hz})$ \\
\hline $2^{\prime}$ & 75.38 & 75.22 & 75.21 & $4.06 \mathrm{t}(8.2 \mathrm{~Hz})$ & $3.13 \mathrm{t}(8.5 \mathrm{~Hz})$ & $3.14 \mathrm{t}(8.5 \mathrm{~Hz})$ \\
\hline 3' & 78.57 & 78.18 & 78.15 & $4.05 \mathrm{t}(8.3 \mathrm{~Hz})$ & $3.33 \mathrm{t}(8.5 \mathrm{~Hz})$ & $3.34 \mathrm{t}(8.5 \mathrm{~Hz})$ \\
\hline 4' & 71.82 & 71.76 & 71.76 & $4.28 \mathrm{t}(8.6 \mathrm{~Hz})$ & $3.25 \mathrm{t}(9.7 \mathrm{~Hz})$ & $3.27 \mathrm{t}(9.6 \mathrm{~Hz})$ \\
\hline 5 , & 78.68 & 77.97 & 77.94 & $4.31 \mathrm{~m}$ & $3.24 \mathrm{~m}$ & $3.27 \mathrm{~m}$ \\
\hline 6 ' & 62.99 & 62.87 & 62.86 & $4.62 ; 4.44 \mathrm{~m}$ & $\begin{array}{l}3.84 \mathrm{dd}(2.2 ; 11.7 \mathrm{~Hz}) ; \\
3.64 \mathrm{dd}(5.0 ; 11.7 \mathrm{~Hz})\end{array}$ & $\begin{array}{l}3.84 \mathrm{dd}(2.2 ; 12.0 \mathrm{~Hz}) \\
3.65 \mathrm{dd}(5.2 ; 12.0 \mathrm{~Hz})\end{array}$ \\
\hline
\end{tabular}

${ }^{\mathrm{a}}$ Solvent: pyridine- $d_{5}$; ${ }^{\mathrm{b}}$ solvent: $\mathrm{CD}_{3} \mathrm{OD}$; ${ }^{\mathrm{c} n o n}$-resolved multiplet. 

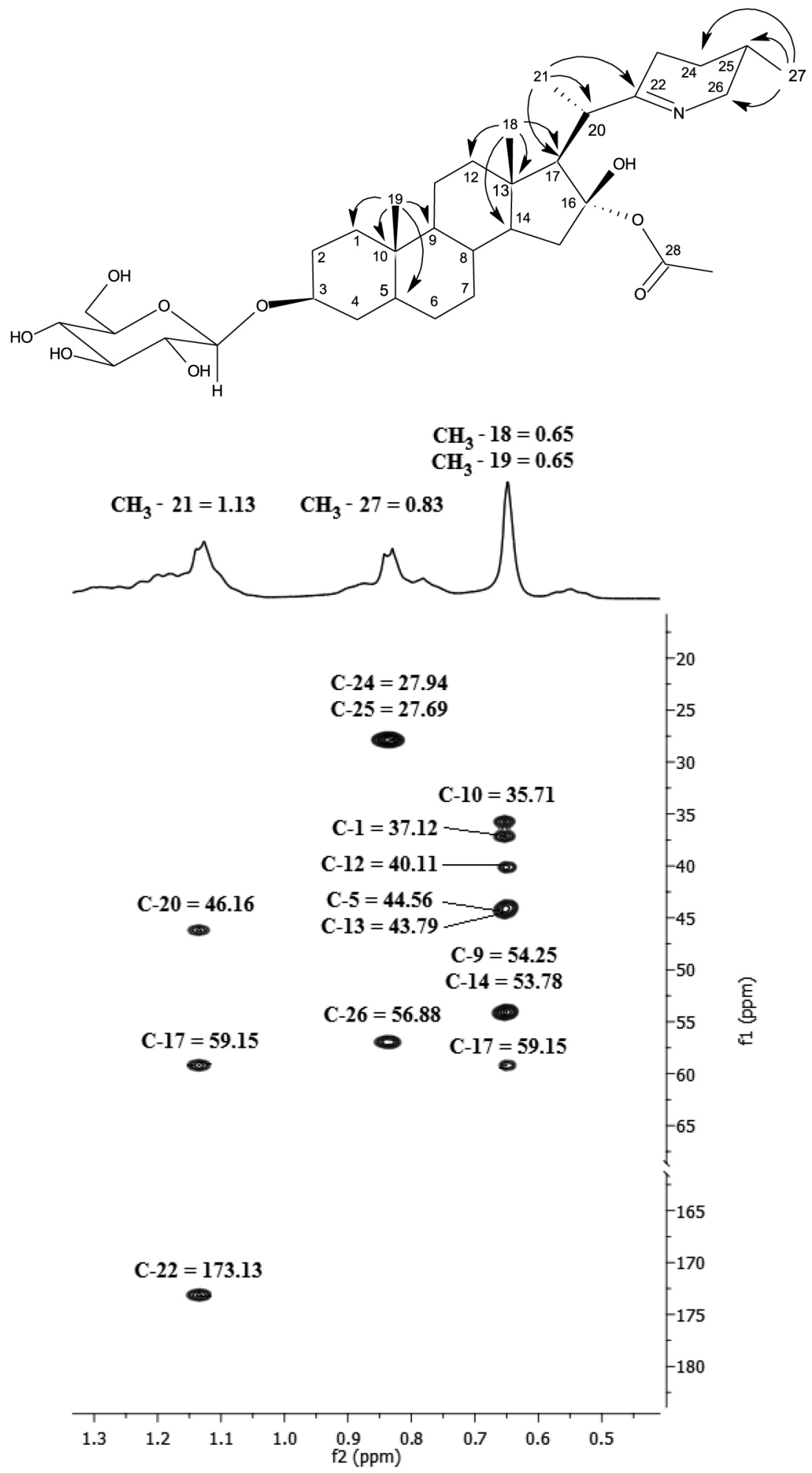

Figure 2. HMBC correlations found for compound $\mathbf{1}$.

The loss of 60.0211 plus 162.0528 mass units observed in the HRESIMS spectrum of $\mathbf{1}$ was taken as evidence that one acetyl and one hexose sugar residue were present. To confirm the identity of the sugar residue, a 1D total correlation spectroscopy (TOCSY) experiment was set up with increasing mixing times from 10 to $200 \mathrm{~ms}$ (array of 5) and selecting the signal attributed to the anomeric hydrogen at $\delta_{\mathrm{H}} 5.05(\mathrm{~d}, J 7.7 \mathrm{~Hz})$. This experiment allowed for the identification of the $J$ connectivity array in the sugar moiety as similar to a $\beta$-anomeric glucopyranosyl residue as: $\delta 5.05$ 
(H-1'), 4.06 (H-2'), 4.05 (H-3'), 4.28 (H-4'), 4.31 (H-5') and 4.62/4.44 (H-6'). ${ }^{13,14}$ The corresponding carbons were assigned by analyzing the edited HSQC spectrum. The observed HMBC cross correlation peak between the carbon signal at $\delta 102.22\left(\mathrm{C}-1^{\prime}\right)$ and the proton signal at $\delta 3.97$ (H-3), indicated that the glucopyranosyl residue was linked to C-3 of the aglycone. This assignment was unambiguously confirmed by the observed ROE correlation between the $\mathrm{H}-1$ ' anomeric proton and $\mathrm{H}-3$. The rotating frame nuclear Overhauser effect spectroscopy (ROESY) experiment also confirmed the equatorial $\beta$ orientation of the oxygen at C-3, as well as the overall stereochemistry of the steroid skeleton. The structure of the epimino ring attached to carbon 20 was deduced as follows: the HMBC correlations of the $\mathrm{C}-27$ ( $\delta$ 19.28) methyl led us to assign carbons (and respective hydrogens via HSQC) at C-24 $(\delta 27.94 ; 1.68$ and 1.18$), \mathrm{C}-25(\delta 27.69 ; 1.53)$ and $\mathrm{C}-26$ ( $\delta 56.88 ; 3.80$ and 3.11 ); on the other hand, the $\mathrm{sp}^{2}$ imino carbon appearing at $\delta 173.13(\mathrm{C}-22)$ displayed correlations with hydrogens at $\delta 3.80 / 3.11$ (H-26 methylene), 2.63 (H-20), 1.68/1.18 (H-24), $2.20(\mathrm{H}-23), 1.88(\mathrm{H}-17)$ and 1.13 $(\mathrm{H}-21)$. Finally, the acetoxy residue was located at C-16 based on the HMBC cross peak between C-28 ( $\delta$ 170.40) and $\mathrm{H}-16(\delta$ 5.27).

The results found so far led us to propose that compound 1 is a $22(N)$-unsaturated 22,26-epimino-5 $\alpha$ cholestane type steroidal alkaloid bearing an acetyl group at $\mathrm{C}-16$ and a $\beta$-anomeric glucopyranosyl residue at C-3. The stereochemistry at C-20 was deduced from the value of the vicinal H-20/H-17 coupling constant $(11.5 \mathrm{~Hz})$, indicating an antiperiplanar orientation between those protons. Additionally, ROE cross peaks were observed between $\mathrm{CH}_{3}-21 / \mathrm{H}-12 \beta$ as well as between $\mathrm{H}-20 / \mathrm{H}-16$ (Figure 3). These results are indicative of an $S$ configuration at C-20. Regarding the 22,26-epimino-22( $N$ )-ene ring, the 1D ${ }^{1} \mathrm{H}$ NMR of compound 1 , dissolved in $\mathrm{CD}_{3} \mathrm{OD}$, displayed a similar coupling pattern for protons $26 \alpha$ $(\delta 2.95 ; 16.8$ and $9.4 \mathrm{~Hz})$ and $26 \beta(\delta 3.52 ; 16.8,4.8$ and $1.5 \mathrm{~Hz}$ ) as the one displayed by etioline, an alkaloid with $20 S, 25 S$ configuration..$^{15}$ Thus, we may conclude that compound $\mathbf{1}$ is 3-O-( $\beta$ - $D$-glucopyranosyl) $(20 S, 25 S)$-22,26epimino-16 $\alpha$-acetyl-cholesta-22( $N)$-ene. The configuration at C-20 and C-25, for this class of alkaloids, is subject of discussion in literature and has been formerly determined by synthesis and, more recently, from scalar coupling and ROE measurements..$^{9,10,15,16}$ Thus, compound $\mathbf{1}$ is a new 25-isosolafloridine type alkaloid bearing an acetyl group at C-16 and a $\beta$-anomeric glucopyranosyl residue at C-3. There is a previous report on the isolation of an alkaloid of similar skeleton but without the acetyl and glycosyl moieties, isolated from Solanum callium. ${ }^{17}$

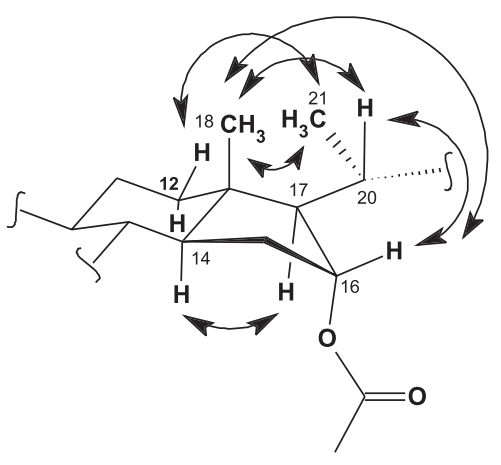

(1)

Figure 3. ROE correlations in compound $\mathbf{1}$.

Compounds 2 and $\mathbf{3}$ display identical molecular formulas, $\mathrm{C}_{35} \mathrm{H}_{53} \mathrm{NO}_{9}$, as determined by positive HRESIMS. The observed protonated molecular ion for $\mathbf{2}$ appeared at $m / z 632.3798[\mathrm{M}+\mathrm{H}]^{+}$( calcd. for $\mathrm{C}_{35} \mathrm{H}_{54} \mathrm{NO}_{9}$ 632.3793) and the sodiated molecular ion at $\mathrm{m} / z 654.3627[\mathrm{M}+\mathrm{Na}]^{+}$ (calcd. for $\mathrm{C}_{35} \mathrm{H}_{53} \mathrm{NNaO}_{9}$ 654.3613). APCIMS ion mass fragments at: $m / z, 572\left[(\mathrm{M}+\mathrm{H})-\mathrm{CH}_{3} \mathrm{CO}_{2} \mathrm{H}\right]^{+}$, $m / z 470[(\mathrm{M}+\mathrm{H})-\text { hexose residue }]^{+}$and $m / z 410$ $\left[(\mathrm{M}+\mathrm{H})-\mathrm{CH}_{3} \mathrm{CO}_{2} \mathrm{H} \text { plus hexose residue }\right]^{+}$were also observed. The observed protonated molecular ion for $\mathbf{3}$ appeared at $632.3790[\mathrm{M}+\mathrm{H}]^{+}$(calcd. for $\mathrm{C}_{35} \mathrm{H}_{54} \mathrm{NO}_{9}$ 632.3793) and $\mathrm{m} / \mathrm{z} 654.3619\left[\mathrm{M}+\mathrm{Na}^{+}\right.$(calcd. for $\mathrm{C}_{35} \mathrm{H}_{53} \mathrm{NNaO}_{9}$ 654.3613). APCIMS ion mass fragments were also observed at: $m / z 572\left[(\mathrm{M}+\mathrm{H})-\mathrm{CH}_{3} \mathrm{CO}_{2} \mathrm{H}\right]^{+}$, $m / z 470[(\mathrm{M}+\mathrm{H})-\text { hexose residue }]^{+}$and $m / z 410$ $\left[(\mathrm{M}+\mathrm{H})-\mathrm{CH}_{3} \mathrm{CO}_{2} \mathrm{H} \text { plus hexose residue }\right]^{+}$. The mass losses of 60 and 162 mass units are indicative of the presence of acetyl and hexosyl moieties in both structures.

The NMR spectral data (Table 1) for compounds 2 and $\mathbf{3}$ are almost superimposable by comparison of their proton and carbon chemical shifts in rings $\mathrm{A}, \mathrm{B}$ and $\mathrm{C}$ of the steroidal backbone and in the sugar residue. Additionally, comparison of the sugar residue chemical shift data for $\mathbf{2}$ and $\mathbf{3}$ confirms that a $\beta$ - $D$-glucopyranosyl unit residue is common to the two compounds. For both 2 and $\mathbf{3}$ compounds 1D TOCSY experiments were set up with increasing mixing times from 10 to $200 \mathrm{~ms}$ and selecting the signal at $\delta_{\mathrm{H}} 4.37(\mathrm{~d}, J 7.7 \mathrm{~Hz})$. These experiments allowed for the identification of the $J$ connectivity array in the sugar moiety as similar to a $\beta$-anomeric glucopyranosyl residue as: (2) $\delta 4.37$ (H-1'), 3.13 (H-2'), 3.33 (H-3'), 3.25 (H-4'), 3.24 (H-5') and 3.84/3.64 (H-6') and for (3) $\delta 4.38$ (H-1'), 3.14 (H-2'), 3.34 (H-3'), 3.27 (H-4'), 3.27 (H-5') and 3.84/3.65 (H-6'). ${ }^{13,14}$ The methyl groups correlations in the HMBC spectrum allowed the assignment of $\mathrm{C}-1$, C-5, C-9, C-10, C-12, C-13, C-14, C-17, C-20, C-22, C-24, $\mathrm{C}-25, \mathrm{C}-26$ and the edited HSQC was used to identify the associated protons. The signals of $\mathrm{H}-3(\delta 3.58), \mathrm{H}-6$ 
$(\delta 5.36), \mathrm{H}-16(\delta 5.02$ and $\delta 5.05)$ were used as entry points in COSY leading to the identification of the neighbor protons (H-2, H-4, H-7, H-15, H-17). Again, edited HSQC helped the identification of the associated carbons. The remaining carbons and protons were assigned on the basis of their chemical shifts (C-22, $\delta 204.07$ and 204.43; $\mathrm{C}-28, \delta 172.5$ and 172.7) and by extensive use of COSY, HSQC and HMBC correlations (protons and carbons at positions 8 and 11). The all-trans fusion of the ring in the steroid backbone was confirmed by a ROESY experiment, for both compounds. The location of the sugar residue at $\mathrm{C}-3$ and the acetoxy group at C-16 were deduced on the grounds of HMBC data as in compound $\mathbf{1}$ and confirmed by ROESY data. The NMR spectra of the alkaloids $\mathbf{2}$ and 3 differed mainly with regard to the chemical shifts of C-13, C-17, C-18, H-12, H-17, H-18, H-20 and H-21. The reason for those discrepancies resides in the fact that the two compounds are epimeric at C-20. In both compounds, a ROE correlation between the H-20 signal and H-18 methyl proton signal was observed, but there was no ROE between the $\mathrm{H}-20$ and the $\mathrm{H}-17$ signals, indicating that, in the favored conformations $\mathrm{H}-17$ lies too far from $\mathrm{H}-20$ to show dipolar coupling. On the other hand, the $\mathrm{CH}_{3}-21$ signal showed ROE correlations with $\mathrm{H}-16$ in 2 ( $R$ configuration at $\mathrm{C}-20$ ) while in $\mathbf{3}$ the $\mathrm{CH}_{3}-21$ signal showed ROE correlations with $\mathrm{H}-12$ and $\mathrm{CH}_{3}-18$ but not with $\mathrm{H}-17$, indicating configuration $S$ at C-20 (Figure 4). These assignments were unambiguously confirmed by the values observed for the vicinal coupling constants between $\mathrm{H}-20$ and $\mathrm{H}-17(10.7 \mathrm{~Hz})$, indicating their antiperiplanar orientation. Compounds 2 (3- $O$ - $(\beta-D$-glucopyranosyl) $(20 R, 25 \xi)$-23,26-epimino-16 $\alpha$-acetyl-cholesta-5,23(N)dien-22-one) and 3 (3- $O$-( $\beta$ - $D$-glucopyranosyl) $(20 S, 25 \xi)$ 23,26-epimino-16 $\alpha$-acetyl-cholesta-5,23( $N$ )-dien-22-one) were thus characterized as solaspiralidine-type alkaloids as the one isolated from S. spirale..$^{10}$ Although the isolation of C-20 epimeric solaspiralidine alkaloids has already been described, e.g., from the bulbs of Fritillaria persica (Liliaceae), ${ }^{18}$ this is the first report on the isolation of C-20 epimeric, 3-O- $\beta$ - $D$-glucosyl, 16-acetyl solaspiralidine alkaloids. This rare structural alkaloid type is characterized by the double bond between $\mathrm{C}-23$ and $\mathrm{N}$ in the fivemembered ring heterocycle and a carbonyl function at $\mathrm{C}-22$. These compounds were originally interpreted as 22,26-epiminocholestanes. ${ }^{3}$

\section{Conclusions}

Three new steroidal glycoalkaloids were isolated from the berries of Solanum pseudoquina A. St.-Hil. (Solanaceae) a bitter tasting plant formerly used in Brazil as

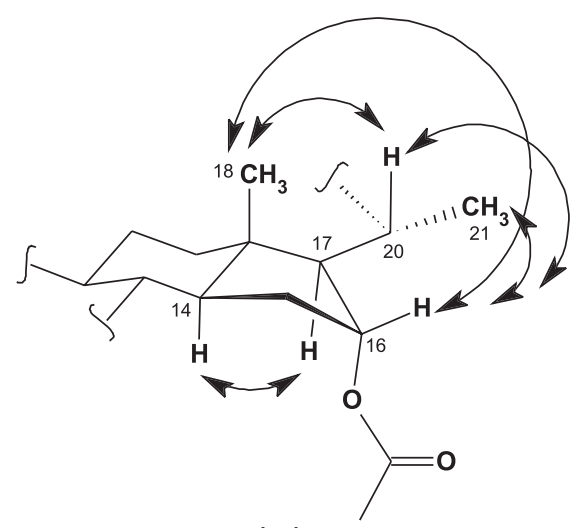

(2)

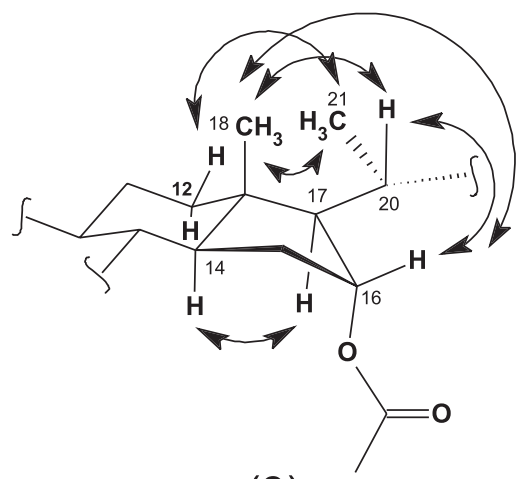

(3)

Figure 4. ROE correlations of compounds $\mathbf{2}$ and $\mathbf{3}$.

substitute of Cinchona spp., in the treatment of intermittent fevers. The alkaloids had their full structures elucidated on the basis of spectroscopic and chemical evidence (nuclear magnetic resonance and mass spectrometry), as: 3- $O$-( $\beta$ - $D$-glucopyranosyl) $(20 S, 25 S)$-22,26-epimino-16 $\alpha$ acetyl-cholesta-22( $N)$-ene, 1, 3- $O$-( $\beta$ - $D$-glucopyranosyl) $(20 R, 25 \xi)$-23,26-epimino-16 $\alpha$-acetyl-cholesta-5,23(N)dien-22-one, 2 and 3-O-( $\beta$ - $D$-glucopyranosyl) $(20 S, 25 \xi)$ $23,26$-epimino- $16 \alpha$-acetyl-cholesta-5,23( $N)$-dien-22one, 3.

\section{Supplementary Information}

Supplementary data are available free of charge at http://jbcs.sbq.org.br as a PDF file.

\section{Acknowledgments}

This research was supported by funds from Fundação de Amparo à Pesquisa do Estado do Rio de Janeiro-FAPERJ, Conselho Nacional de Desenvolvimento Científico e Tecnológico-CNPq and Coordenação de Aperfeiçoamento de Pessoal de Nível Superior-CAPES. 


\section{References}

1. Mors, W. B.; Rizzini, C. T.; Pereira, N. A.; Medicinal Plants of Brazil; Reference Publications Inc.: Algonac, Michigan, 2000.

2. Cosenza, G. P.; Somavilla, N. S.; Fagg, C. W.; Brandão, M. G. L.; J. Ethnopharmacol. 2013, 149, 790.

3. Eich, E.; Solanaceae and Convolvulaceae: Secondary Metabolites; Springer-Verlag Berlin Heidelberg: Springer, 2008.

4. Usubillaga, A.; de Castellano, G.; Hidalgo, J.; Guevara, C.; Martinod, P.; Paredes, A.; Phytochemistry 1977, 16, 1861.

5. Meccia, G.; Usubillaga, A. N.; J. Nat. Prod. 1987, 50, 642.

6. Oliveira, R. A. G.; Bhattacharyya, J.; Carvalho, L. A. E.; Leonart, R.; Paulo, M. Q.; Trolin, G.; J. Ethnopharmacol. 1988, $24,155$.

7. Milner, S. E.; Brunton, N. P.; Jones, P. W.; O’Brien, N. M.; Collins, S. G.; Maguire, A. R.; J. Agric. Food Chem. 2011, 59, 3454.

8. Cham, B. E.; Mod. Chemother. 2013, 2, 33.

9. Ripperger, H.; Sych, F.-J.; Schreiber, K.; Tetrahedron 1972, 28, 1619.
10. Ripperger, H.; Phytochemistry 1996, 43, 705.

11. Lu, Y.; Luo, J.; Kong, L.; Phytochemistry 2011, 72, 668.

12. da Silva, A. J. R.; Borges, R. M.; Soares, V. In Modern NMR Approaches to the Structure Elucidation of Natural Products: Data Acquisition and Applications to Compound Classes, vol. 2, $1^{\text {st }}$ ed.; Williams, A.; Martin, G.; Rovnyak, D., eds.; Royal Society of Chemistry: London, England, 2016, ch. 9.

13. Agrawal, P. K.; Phytochemistry 1992, 31, 3307.

14. Duus, J. O.; Gotfredsen, C. H.; Bock, K.; Chem. Rev. 2000, $100,4589$.

15. Ripperger, H.; Phytochemistry 1990, 29, 3375.

16. Ripperger, H.; Phytochemistry 1996, 41, 1629.

17. Bird, G. J.; Collins, D. J.; Eastwood, F. W.; Gatehouse, B. M. K. C.; Jossa, A. J.; Swan, J. M.; Tetrahedron Lett. 1976, 40, 3653.

18. Ori, K.; Mimaki, Y.; Sashida, Y.; Nikaido, T.; Ohmoto, T.; Phytochemistry 1992, 31, 4337.

Submitted: April 24, 2016 Published online: August 9, 2016 